\title{
PERLINDUNGAN HUKUM BAGI BANK PEMEGANG HAK TANGGUNGAN PERINGKAT KEDUA DALAM EKSEKUSI OBJEK HAK TANGGUNGAN
}

\author{
Dimas Nur Arif Putra Suwandi \\ dimasnurarif@rocketmail.com \\ Universitas Airlangga
}

\begin{abstract}
The provision of credit by banks as a financial institution is certainly full of risks, so the Bank is required to manage these risks, therefore risk management is needed. Risk management is defined as a series of methodologies and procedures used to identify, measure, monitor and control risks arising from all of the Bank's business activities. So that it should be able to provide legal protection for credit providers and recipients as well as related parties to get protection through a legal guarantee institution for all interested parties. Whereas with regard to one guarantee object, the mortgage rights that are burdened with more than one of the mortgage rights, can be submitted to more than 1 (one) Bank or submitted to the same Bank as the first liability holder. However, the ranking in the mortgage rights is often a problem in the execution of its execution. Whereas the legal protection is often not obtained by the Bank as the second rank creditor, because in the execution of the Underwriting Right object, there is a rejection from the KPKNL because the Bank is not the first holder of the Underwriting Right. This article aims to examine the position of the secondranked creditor in the execution of mortgage rights when the first ranking mortgage rights have been carried out because the first credit has been paid off, while the second rank will execute the Underwriting Right object with a ranking basis but often the Auction Hall refuses on the grounds of Article 6 Act Number 4 of 1996 on Land Underwriting Rights and Objects Related to Land.
\end{abstract}

Keywords: Execution of second rank Mortgage Rights Object; Priority Principle; KPKNL Rejection.

\begin{abstract}
Abstrak
Pemberian kredit yang dilakukan oleh bank sebagai suatu lembaga keuangan tentunya sarat akan resiko, maka Bank wajib untuk mengelola resiko tersebut, oleh karena itu diperlukan adanya manajemen resiko. Manajemen resiko diartikan sebagai serangkaian metodologi dan prosedur yang digunakan untuk mengidentifikasi, mengukur, memantau, dan mengendalikan risiko yang timbul dari seluruh kegiatan usaha Bank. Sehingga sudah semestinya harus dapat memberikan perlindungan hukum bagi pemberi dan penerima kredit serta pihak yang terkait mendapat perlindungan melalui suatu lembaga jaminan hukum bagi semua pihak yang berkepentingan. Bahwa terhadap satu objek jaminan hak tanggungan yang dibebani lebih dari satu hak tanggungan tersebut, dapat diajukan pada lebih dari 1 (satu) Bank ataupun diajukan pada Bank yang sama dengan pemegang hak tanggungan yang pertama. Namun adanya peringkat dalam hak tanggungan tersebut seringkali menjadi permasalahan dalam pelaksanaan eksekusinya. Bahwa perlindungan hukum tersebut seolah seringkali tidak didapatkan oleh Bank selaku kreditur peringkat kedua, karena dalam pelaksanaan eksekusi objek Hak Tanggungan terjadi penolakan dari KPKNL karena kedudukan Bank bukan sebagai pemegang Hak Tanggungan peringkat pertama. Artikel ini bertujuan untuk menelaah kedudukan Kreditur peringkat kedua dalam pelaksanaan eksekusi hak tanggungan ketika hak tanggungan peringkat pertama sudah dilakukan roya karena kredit pertama sudah lunas, sedangkan peringkat kedua akan melakukan eksekusi atas objek Hak Tanggungan dengan dasar peringkat namun seringkali Balai Lelang menolak dengan alasan ketentuan Pasal 6 Undang-undang Nomor 4 Tahun 1996 tentang Hak Tanggungan Atas Tanah Beserta Benda-benda Yang Berkaitan Dengan Tanah.
\end{abstract}

Kata Kunci: Eksekusi Objek Hak Tanggungan peringkat kedua; Asas Prioritas; Penolakan KPKNL. 


\section{Pendahuluan}

Dalam dunia kewirausahaan sering dijumpai permasalahan mengenai keinginan untuk mengembangkan usaha namun terkedala dengan modal yang tidak mencukupi. Dana yang diperoleh melalui perkreditan salah satunya dapat bersumber dari Bank, lembaga pembiayaan lain, atau dari sumber-sumber pembiayaan lainnya.

Seorang nasabah yang mendapatkan kredit dari bank memang adalah seorang yang mendapat kepercayaan dari bank. ${ }^{1}$ Adapun pengertian kredit menurut Pasal 1 angka 2 UU Perbankan adalah "Kredit adalah penyediaan uang atau tagihan yang dapat dipersamakan dengan itu, berdasarkan persetujuan atau kesepakatan pinjam meminjam antara Bank dengan pihak lain yang mewajibkan pihak peminjam untuk melunasi hutangnya setelah jangka waktu tertentu dengan jumlah bunga”.

Mengingat pentingnya kedudukan kredit dalam dunia usaha, sudah seharusnya bila pemberi kredit dan penerima kredit dan juga pihak lainnya, mendapat perlindungan hukum dari suatu lembaga jaminan yang kuat dan dapat memberikan kepastian hukum bagi semua pihak yang berkepentingan yang diatur dalam suatu aturan khusus tentang itu. Peraturan-peraturan demikian kiranya harus cukup meyakinkan dan memberikan kepastian hukum bagi lembaga-lembaga pemberian kredit, baik dari dalam maupun luar negeri. ${ }^{2}$

Pemberian kredit oleh bank sebagai salah satu lembaga keuangan tentunya sarat akan resiko, maka Bank wajib untuk mengelola resiko tersebut, oleh karena itu diperlukan adanya manajemen resiko. Manajemen resiko diartikan sebagai serangkaian metodologi dan prosedur yang digunakan untuk mengidentifikasi, mengukur, memantau, dan mengendalikan risiko yang timbul dari seluruh kegiatan usaha Bank. ${ }^{3}$

Dalam Pasal 1131 BurgerlijkWetboek (selanjutnya disebut BW) terdapat ketentuan yang berlaku terhadap semua debitur dan kreditur serta demi hukum

\footnotetext{
${ }^{1}$ R. Subekti, Jaminan-jaminan Untuk Pemberian Kredit Menurut Hukum Indonesia (Citra Adita Bakti 1989).[1].

${ }^{2}$ Rachmadi Usman, Pasal-pasal Tentang Hak Tanggungan atas Tanah (Djambatan 1999).[22].

3 Trisadini P. Usanti, Abd. Shomad, Hukum Perbankan (Kencana 2017).[189].
} 
berlaku tanpa adanya perjanjian sebelumnya, yang menyatakan "Segala kebendaan si berutang, baik yang bergerak maupun yang tak bergerak, baik yang sudah ada maupun yang akan ada dikemudian hari, menjadi tanggungan untuk segala perikatannya perseorangan."

Sehingga jelas ketentuan Pasal 1131 BW tersebut adalah suatu aturan yang mengatur mengenai jaminan dan bersifat umum. Sedangkan ketentuan Pasal 1132 BW menegaskan "Kebendaan tersebut menjadi jaminan bersama-sama bagi semua orang yang mengutangkan padanya, pendapatan penjualan benda-benda itu dibagi-bagi menurut keseimbangan, yaitu menurut besar kecilnya piutang masingmasing, kecuali apabila diantara para kreditur itu ada alasan-alasan yang sah untuk didahulukan.” J. Satrio mengemukakan, bahwa dari Pasal 1131 BW dapat disimpulkan asas-asas hubungan ekstern kreditur sebagai berikut: ${ }^{4}$

1. Seorang kreditur dapat mengambil pelunasan dari setiap bagian dari harta kekayaan debitur;

2. Setiap bagian kekayaan debitur dapat dijual untuk pelunasan tagihan kreditur; 3. Hak tagihan kreditur hanya dijamin dengan harta benda debitur saja.

Hak atas tanah dinilai sebagai jaminan yang penting dalam pemberian atau permohonan kredit, karena selain dianggap paling aman untuk dijadikan sebagagai jaminan, tanah juga mudah untuk dijual, dan dari segi harga juga terus meningkat, tidak gampang musnah, memiliki tanda bukti hak serta dapat dibebani dengan hak tanggungan yang memberikan kedudukan istimewa kepada kreditur sebagai kreditur preferen.

Tanah sebagai jaminan suatu kredit, didasarkan pada Undang-undang Nomor 5 tahun 1960 tentang Peraturan Dasar Pokok-Pokok Agraria (selanjutnya disebut UUPA) dan Undang-undang Nomor 4 Tahun 1996 tentang Hak Tanggungan Atas Tanah Beserta Benda-benda Yang Berkaitan Dengan Tanah (selanjutnya disebut Undang-undang Hak Tanggungan).

Hak Tanggungan adalah hak jaminan atas tanah guna pelunasan utang yang

${ }^{4}$ Rachmadi Usman.Op.Cit.[27]. 
kedudukan krediturnya diutamakan daripada kreditur lain. Sehingga apabila debitur cidera janji, kreditur sebagai pemegang Hak Tanggungan dapat menjual obyek Hak Tanggungan melalui penjualan dimuka umum atau pelelangan. Pada dasarnya perjanjian Hak Tanggungan merupakan perjanjian ikutan (accessoir) yang mengikuti perjanjian pokok.

Dalam pemberian Hak Tanggungan atas Kredit yang berbeda, apabila pihak kreditur merasa yakin dengan kemampuan Debitur dan agunan yang dijaminkan masih mencukupi untuk diagunkan kembali, dapat dilakukan Pengikatan Hak Tanggungan Peringkat Kedua. Kreditur tersebut sebelumnya meskipun sudah mengikat tanah tersebut dengan Hak Tanggungan Peringkat Pertama Hal tersebut tidak dilarang oleh Undang-undang Hak Tanggungan. Akan tetapi, dalam Pelaksanaan eksekusi mengalami kesulitan dikarenakan ketika Peringkat Pertama sudah dilakukan roya karena kredit pertama sudah lunas, sedangkan peringkat kedua akan melakukan eksekusi atas objek Hak Tanggungan dengan dasar peringkat namun seringkali Balai Lelang menolak dengan alasan ketentuan Pasal 6 Undang-undang Hak Tanggungan yang menyatakan : “Apabila debitor cidera janji, pemegang Hak Tanggungan pertama mempunyai hak untuk menjual obyek Hak Tanggungan atas kekuasaan sendiri melalui pelelangan umum serta mengambil pelunasan piutangnya dari hasil penjualan tersebut".

Berdasarkan uraian di atas, pelaksanaan eksekusi objek hak tanggungan peringkat kedua sangat menarik untuk dikaji lebih mendalam, dikaitkan dengan Peringkat Hak Tanggungan sebagai perwujudan dari Asas Prioritas dan Upaya yang dapat dilakukan Bank sebagai pemegang Hak Tanggungan Peringkat kedua apabila lelang objek Hak Tanggungan Peringkat Kedua tidak dapat dilaksanakan.

\section{Peringkat Hak Tanggungan Sebagai Perwujudan Dari Asas Prioritas Proses Pembebanan Hak Tanggungan}

Bahwa pembebanan Hak Tanggungan pada objek tanah adalah sebagai berikut :

a. Tahap pemberian Hak Tanggungan 
Prosesnya diawali dengan dibuatnya perjanjian kredit (perjanjian pokok). Bahwa setelah perjanjian kredit atau perjanjan pokok dibuat, barulah dibuat perjanjian ikutannya atau Perjanjian Pemberian Hak Tanggungan. Hal tersebut sebagaimana ketentuan Pasal 10 ayat (1) Undang-undang Hak Tanggungan.

Bahwa tahapan pemberian Hak Tanggungan tersebut dilakukan di hadapan PPAT dengan dibuatnya APHT, yang bentuk dan isinya ditetapkan dengan Peraturan Menteri Negara Agraria/Kepala BPN Nomor 3 Tahun 1996. ${ }^{5}$

Di dalam APHT dapat dicantumkan janji yang disampaikan oleh para pihak, sebagaimana dimaksud dalam ketentuan Pasal 11 ayat (2) Undang-undang Hak Tanggungan. Bahwa apa yang disebut dalam ayat (1) yang merupakan isi wajib dari perjanjian hak tanggugan, berbeda dengan apa yang diatur dalam ayat (2) yang mengatur mengenai isi janji yang sifatnya tidak wajib atau dapat dikurangi ataupun ditambah, namun tidak boleh bertentangan dengan ketentuan dalam Undang-undang Hak Tanggungan.

Ketentuan-ketentuan mengenai isi dalam APHT tersebut sifatnya wajib dan berpengaruh pada sah tidaknya pemberian Hak Tanggungan. Kalau tidak dicantumkan secara lengkap APHT yang bersangkutan Batal Demi Hukum. ${ }^{6}$

Bahwa isi APHT sebagaimana dimaksud dalam ketentuan Pasal 11 ayat (2) Undang-undang Hak Tanggungan adalah salah satu upaya kreditur untuk menjaga agar objek jaminan tetap bernilai tinggi, terlebih pada saat dilaksanakannya eksekusi.

b. Tahap Pendaftaran Hak Tanggungan

Bahwa dengan didaftarkannya Hak Tanggungan (APHT) ke Kantor Pertanahan setempat, maka moment tersebut adalah moment lahirnya Hak Tanggungan yang dibebankan. Dengan lahirnya Hak Tanggungan, maka lahir pula hak istimewa atau kedudukan istimewa (droit de preference) dari pemegang Hak Tanggungan.

5 Boedi Harsono, Hukum Agraria Indonesia, Sejarah Pembentukan Undang-undang Pokok Agraria, Isi dan Pelaksanaannya (Djambatan 2007).[432].

${ }^{6}$ Ibid.[438]. 
APHT yang dibuat oleh PPAT wajib didaftarkan ke Kantor Pertanahan setempat selambat-lambatnya 7 (tujuh) hari kerja setelah penandatanganan APHT. Pendaftaran dilakukan dengan cara mencatatnya kedalam buku tanah hak atas tanah yang menjadi obyek Hak Tanggungan dan menyalin catatan tersebut ke sertifikat hak atas tanah.

Selanjutnya Kantor Pertanahan setempat menerbitkan Sertifikat Hak Tanggungan (untuk selanjutnya dalam tulisan ini disingkat (SHT)) sebagai tanda bukti Hak Tanggungan, yang memuat irah-irah "Demi Keadilan Berdasarkan Ketuhanan Yang Maha Esa”, yang memberikan titel eksekutorial kepada SHT tersebut, sehingga SHT tersebut mempunyai kekuatan yang sama dengan putusan hakim yang telah mempunyai kekuatan hukum tetap, serta dapat berlaku juga sebagai pengganti Grosse Akta Hipotek, yang dapat dimohonkan eksekusinya ke Pengadilan Negeri berdasarkan ketentuan Pasal 258 RBg (Pasal 224 HIR).

\section{Asas Prioritas Dalam Hak Tanggungan}

Jaminan kebendaan termasuk dalam hukum kebendaan, sehingga ciri-ciri hak kebendaan berlaku pula pada jaminan kebendaan. Hak jaminan kebendaan memberikan hak-hak kepada kreditur untuk didahulukan dalam pengambilan pelunasan dibandingkan kreditur-kreditur lain yang tidak memiliki hak jaminan kebendaan.

Bahwa ciri-ciri hak kebendaan yang berlaku dalam hukum hak tanggungan salah satunya adalah asas prioritas, yaitu hak kebendaan yang terlebihdahulu lahir atau terjadi akan lebih diutamakan daripada yang terjadi kemudian (droit de preference), tetapi kedudukan diutamakan tersebut tidak mengurangi hak preferensi dari negara terhadap piutang-piutang yang menurut ketentuan hukum yang berlaku seperti pada Pasal 20 Ayat (1) Undang-undang Hak Tanggungan.

Dalam hukum Hak Tanggungan sangat dimungkinkan bahwa terhadap satu objek jaminan dapat dibebani lebih dari satu hak tanggungan, dimana hal tersebut juga digantungkan pada ketentuan bahwa nilai objek jaminan hak tanggungan tersebut harus melebihi jumlah total hutangnya. Bahwa terhadap satu objek jaminan 
hak tanggungan yang dibebani lebih dari satu hak tanggungan tersebut, dapat diajukan pada lebih dari satu Bank ataupun diajukan pada Bank yang sama dengan pemegang hak tanggungan yang pertama.

Bahwa terhadap satu objek jaminan yang dibebani lebih dari satu hak tanggungan,makaperingkatdarimasing-masinghaktanggunganakanmempengaruhi urutan prioritas pelunasan hutang (droit de preference). Sedangkan peletakan atau pemberian peringkat pada masing-masing hak tanggungan, didasarkan pada waktu pendaftaran hak tanggungan tersebut pada Kantor Pertanahan, atau apabila terdapat lebih dari satu pendaftaran hak tanggungan yang dilakukan pada hari yang sama, maka pemberian peringkat hak tanggungan tersebut berikan berdasarkan urutan tanggal pembuatan APHT. Hal tersebut sebagaimana tertuang pada ketentuan Pasal 5 Undang-undang Hak Tanggungan.

Asas Prioritas tersebut juga berlaku dalam keadaan apabila terhadap satu objek jaminan dibebani lebih dari satu hak tanggungan, maka apabila hak tanggungan peringkat pertamanya telah hapus karena hal-hal sebagaimana dimaksud dalam ketentuan Pasal 18 ayat (1) Undang-undang Hak Tanggungan, maka berdasarkan Asas Prioritas tersebut kedudukan pemegang hak tanggungan peringakat kedua secara otomatis menggantikan kedudukan pemegang hak tanggungan peringkat pertama, sehingga menempatkan pemegang hak tanggungan peringkat kedua sebagai pihak yang mempunyai hak untuk menjual objek Hak Tanggungan atas kekuasaan sendiri melalui penjualan umum (lelang) serta mengambil pelunasan piutangnyaterlebih dahulu dari hasil penjualan tersebut. Hal tersebut karena dengan hapusnya perikatan antara Bank selaku pemegang Hak Tanggungan peringkat pertama dengan Debitur, maka hapus pula Hak Tanggungan peringkat pertamanya. Bahwa dengan hapusnya Hak Tanggungan peringkat pertamanya, maka dengan sendirinya kedudukan pemegang Hak Tanggungan peringkat keduanya naik dan menggantikan menjadi pemegang Hak Tanggungan peringkat pertama.

Bahwa hak tanggungan tidak akan berakhir sekalipun objek Hak Tanggungan 
itu beralih kepada pihak lain oleh sebab apa pun juga. ${ }^{7}$ Berdasarkan asas tersebut, pemegang Hak Tanggungan selalu dapat menjalankan haknya dan tidak peduli dalam penguasaan siapa objek tersebut berpindah. Hal tesebut merupakan materialisasi dari asas droit de suite atau zaakgevolg sebagaimana tertuang dalam ketentuan Pasal 7 Undang-Undang Hak Tanggungan.

Asas Hak Tanggungan tersebut berkaitan dengan pencegahan akan timbulnya cedera janji dari pemegang Hak Tanggungan. Maka dari itu, bila terjadi cedera janji, pemegang Hak Tanggungan pertama akan mendapat prioritas pertama untuk menjual objek Hak Tanggungan, hal tersebut sesuai ketentuan Pasal 6 Undangundang Hak Tanggungan.

Berkaitan dengan ketentuan Pasal 6 Undang-undang Hak Tanggungan di atas, dalam penjelasannya dijelaskan "Hak untuk menjual objek Hak Tanggungan atas kekuasaan sendiri merupakan salah satu perwujudan dari kedudukan diutamakan yang dipunyai oleh pemegang Hak Tanggungan atau pemegang Hak Tanggungan pertama dalam hal terdapat lebih dari satu pemegang Hak Tanggungan”.

Bahwa ketentuan Pasal 6 Undang-undang Hak Tanggungan tersebut merupakan perwujudan dari asas prioritas yang termaksud dalam ketentuan Pasal 5 Undang-undang Hak Tanggungan, sehingga dalam menafsirkan ketentuan Pasal 6 Undang-undang Hak Tanggungan tersebut haruslah dikaitkan dengan asas prioritas yang tertuang dalam ketentuan Pasal 5 Undang-undang Hak Tanggungan, dimana hal tersebut pada dasarnya telah pula diamanatkan oleh penjelasan Pasal 6 Undang-undang Hak Tanggungan. Bahwa apabila ditafsirkan secara kaku dengan mendasarkan pada bunyi Pasal 6 Undang-undang Hak Tanggungan tersebut, maka hanya pemegang Hak Tanggungan Peringkat pertama sajalah yang dapat atau berhak untuk menjual objek Hak Tanggungan atas kekuasaan sendiri melalui penjualan umum (pelelangan) dan mengambil pelunasan piutangnya terlebihdahulu dari hasil penjualan tersebut, dimana penafsiran atau pandangan tersebut adalah tidak tepat.

\footnotetext{
${ }^{7}$ Sutan Remy Sjahdeini, Hak Tanggungan : Asas-asas Ketentuan-ketentuan Pokok dan Masalah yang Dihadapi Oleh Perbankan (Suatu Kajian Mengenai Undang-undang Hak Tanggungan) (Alumni 1999).[10].
} 
Bahwa berdasarkan penjelasan Pasal 6 Undang-undang Hak Tanggungan maka menjadi jelas bahwa apabila hanya ada satu pemegang Hak Tanggungan, maka ia menjadi satu-satunya pemegang Hak Tanggungan yang berhak untuk menjual melalui penjualan umum (pelelangan) objek Hak Tanggungan atas kekuasaan sendiri serta mengambil pelunasan piutangnya terlebihdahulu dari hasil penjualan tersebut.

Hal tersebut berlaku pula dalam hal terhadap satu objek jaminan dibebani lebih dari 1 (satu) hak tanggungan, apabila kedudukan Hak Tanggungan peringkat pertamanya telah hapus, maka mendasarkan pada penjelasan Pasal 6 Undangundang Hak Tanggungan tersebut, maka kedudukan pemegang Hak Tanggungan peringkat kedua akan menggantikan kedudukan pemegang Hak Tanggungan peringkat pertama serta pemegang Hak Tanggungan peringkat kedua diberikan hak untuk menjual melalui penjualan umum (pelelangan) objek Hak Tanggungan atas kekuasaan sendiri serta mengambil pelunasan piutangnya terlebihdahulu dari hasil penjualan tersebut, sebagaimana ketentuan Pasal 6 Undang-undang Hak Tanggungan.

Bahwa Hak untuk menjual objek Hak Tanggungan atas kekuasaan sendiri tersebut didasarkan pada janji-janji yang diberikan oleh pemegang Hak Tanggungan sebagaimana tertuang dalam APHT, yang pada pokoknya menjelaskan bahwa apabila debitur cedera janji, maka kreditur atau pemegang Hak Tanggungan dapat dan berhak untuk menjual objek Hak Tanggungan tersebut melalui penjualan umum (pelelangan) tanpa memerlukan persetujuan dari pemberi Hak Tanggungan dan kemudian mengambil pelunasan piutangnya terlebihdahulu dari hasil penjualan itu dibanding kreditur-kreditur yang lain, hal tersebut juga biasa disebut parate eksekusi. Bahwa dalam proses tersebut apabila terdapat sisa dari hasil penjualan objek hak tanggungan, maka sisa tersebut menjadi hak dari pemegang Hak Tanggungan.

Berdasarkan hal tersebut maka parate eksekusi dalam Hipotek adalah berbeda dengan parate eksekusi dalam Hak Tanggungan. Perbedaannya, pada Hipotek pemegang Hipotek hanya bisa melakukan parate eksekusi bila sebelumnya telah terlebih dahulu diperjanjikan. Namun berbeda dengan Hak Tanggungan, parate 
eksekusi merupakan hak yang dilekatkan oleh ketentuan Pasal 6 Undang-undang Hak Tanggungan, sehingga diperjanjikan atau tidak sebelumnya, hak tersebut demi hukum telah dimiliki oleh pemegang Hak Tanggungan.

\section{Ciri-ciri Hak Tanggungan}

Dalam penjelasan umum disebutkan bahwa Hak Tanggungan sebagai lembaga hak jaminan atas tanah yang kuat harus mengandung ciri-ciri: ${ }^{8}$

a. Memberikan kedudukan yang diutamakan atau didahulukan bagi pemegangnya (droit de preference);

b. Selalu mengikuti objek jaminan tidak peduli dalam penguasaan siapa pun objek itu berada (droit de suite);

c. Memenuhi asas Spesialitas dan asas Publisitas sehingga dapat mengikat pihak ketiga serta dapat memberikan kepastian hukum kepada pihak yang berkepentingan;

d. Mudah dan pasti pelaksanaan eksekusinya.

\section{Upaya Yang Dapat Dilakukan Bank Sebagai Pemegang Hak Tanggungan} Peringkat Kedua Apabila Lelang Objek Hak Tanggungan Peringkat Kedua Tidak Dapat Dilaksanakan

\section{Eksekusi Hak Tanggungan}

Bahwa pelaksanaan eksekusi objek Hak Tanggungan telah diatur dalam ketentuan Pasal 20 ayat (1) dan ayat (2) Undang-undang Hak Tanggungan, yaitu dengan cara :

1) Berdasar kekuasaan sendiri menjual objek Hak Tanggungan, sebagaimana dimaksud ketentuan Pasal 6 Undang-undang Hak Tanggungan;

2) Dengan dasar titel eksekutorial yang tertuang dalam Sertifikat Hak Tanggungan, sebagaimana dimaksud dalam ketentuan Pasal 14 ayat (2) Undang-undang Hak Tanggungan.

3) Atas kesepakatan antara pemberi dan pemegang Hak Tanggungan, penjualan objek Hak Tanggungan dilaksanakan dengan cara dibawah tangan, jika dengan

\footnotetext{
${ }^{8}$ Kashadi, Hukum Jaminan Ringkasan Kuliah (Universitas Diponegoro 2009).[280].
} 
cara itu akan mendapatkan harga tertinggi yang menguntungkan semua pihak.

Bahwa dalam kajian ini, lebih difokuskan pada kondisi bahwa antara Kreditur dan Debitur dalam keadaan yang tidak lagi harmonis, sehingga tidak memungkinkan lagi untuk membuat Akta Hak Tanggungan yang baru/ peningkatan dari Hak Tanggungan peringkat kedua menjadi Hak Tanggungan peringkat pertama, termasuk tidak mungkin juga untuk membuat kesepakatan mengenai penjualan objek Hak Tanggungan di bawah tangan sebagaimana dimaksud ketentuan Pasal 20 ayat (2) Undang-undang Hak Tanggungan, sehingga pembahasan mengenai cara pelaksanaan eksekusi Hak Tanggungan dalam kajian ini akan difokuskan pada caracara diluar peningkatan Akta Hak Tanggungan dan Kesepakatan penjualan objek Hak Tanggungan di bawah tangan.

\section{Perlindungan Hukum Terhadap Bank apabila Objek Hak Tanggungan Tidak Dapat dieksekusi}

Perlindungan hukum bagi masyarakat dibedakan dua, yaitu secara preventif atau dalam hal pencegahan terjadinya sengketa, sedangkan secara represif setelah diambil suatu keputusan yang dilakukan pemerintah dan beberapa sekelompok masyarakat tidak bisa menerima hal tersebut dan akhirnya memicu sengketa maka hal tersebut harus diselesaikan dengan bahasa sederhannya menyelesaikan sengketa yang telah terjadi. ${ }^{9}$

Dalam kajian yang diuraikan oleh penulis di sub bab sebelumnya, maka terdapat beberapa alternatif upaya yang dapat dilakukan bank sebagai pemegang hak tanggungan peringkat kedua apabila lelang objek hak tanggungan peringkat kedua tidak dapat dilaksanakan yaitu :

a. Fiat Eksekusi

Salah satunya dengan melakukan permohonan pelaksanaan eksekusi objek Hak Tanggungan kepada Ketua Pengadilan, cara ini merupakan alternatif terakhir setelah usaha penjualan dibawah tangan atau penjualan atas kekuasaan sendiri 2007).[10]. 
(parate eksekusi) gagal dilaksanakan. Kendati sebagai alternatif terakhir namun dalam praktik cara ini sering dipakai oleh pihak perbankan. Jika debitur ingkar janji, maka Bank (kreditur) umunya akan meminta Pengadilan Negeri untuk melaksanakan eksekusi Hak Tanggungan berdasarkan titel eksekutorial yang terdapat pada sertifikat hak tanggungan. Hal tersebut sebagaimana ketentuan Pasal 224 HIR dan Pasal 258 RBg yang mengatur eksekusi terhadap dokumen atau grosse akta yang mempunyai titel eksekutorial selain putusan pengadilan.

Eksekusi tersebut dilakukan kreditur dengan mengajukan permohonan kepada Ketua Pengadilan Negeri agar terhadap sertifikat hak tanggungan tersebut dilakukan eksekusi. Permohonan tersebut diajukan dengan cara menyerahkan sertifikat hak tanggungan kepada Ketua Pengadilan Negeri yang disertai dengan permohonan agar diterbitkan fiat eksekusi atau surat perintah eksekusi, sehingga eksekusi dapat dijalankan bahkan dengan bantuan aparat keamanan sekalipun. Cara demikian lebih efektif karena tidak membutuhkan proses litigasi dalam arti tidak harus menunggu proses yang memakan waktu lama dengan biaya yang besar.

Fiat eksekusi merupakan salah satu cara eksekusi hak tanggungan yang dilaksanakan oleh Kantor lelang setelah mendapat ijin atau persetujuan dalam bentuk penetapan dari Ketua Pengadilan Negeri. Eksekusi yang demikian adalah berbeda dengan eksekusi secara parate eksekusi yang dapat dilaksanakan langsung oleh kreditur tanpa meminta penetapan atau fiat eksekusi dari Ketua Pengadilan Negeri. Sehingga Fiat eksekusi adalah cara eksekusi yang dilaksanakan dengan mendasarkan pelaksaannya pada ijin khusus dari Ketua Pengadilan Negeri. Terhadap permohonan fiat eksekusi pihak Pengadilan Negeri cukup melakukan pemeriksanaan terhadap syarat-syarat formal yang telah ditentukan. ${ }^{10}$

Berdasarkan fiat eksekusi tersebut kemudian ditindaklanjuti dengan terbitnya surat perintah penjualan lelang, maka kemudian Kantor Lelang melaksanakan mekanisme penjualan umum (pelelangan) atas objek Hak

${ }^{10}$ Munir Fuady, Hukum Bisnis dalam Teori dan Praktek, Buku Kedua (Citra Aditya Bakti 1994).[64]. 
Tanggungan. Namun sebelum penerbitan fiat eksekusi, terlebih dahulu debitur diberikan peringatan (aanmaning) agar dalam jangka waktu tertentu debitur memenuhi kewajibannya secara sukarela. Apabila setelah diberikan peringatan (aanmaning) debitur tidak menanggapi atau tidak melaksanakan kewajibannya secara sukarela, maka Ketua Pengadilan Negeri akan menerbitkan surat perintah eksekusi yang diikuti perintah penyitaan untuk selanjutnya diterbitkan perintah penjualan lelang kepada Kantor Lelang. ${ }^{11}$

Dalam mekanisme ini, Ketua Pengadilan Negeri berkedudukan sebagai penjual lelang atau pemohon lelang dihadapan Kantor Lelang yang bertindak untuk kepentingan kreditur, termasuk dalam menentukan syarat-syarat lelang. Sebelum penjualan dimuka umum (pelelangan) dilaksanakan, harus terlebihdahulu diumumkan secara berturut-turut dalam tenggang waktu 15 hari melalui surat kabar (Pasal 200 ayat (7) Herziene Indsland Reglement (H.I.R)) sebanyak dua kali pengumuman. Bahwa sebelum pengumuman lelang diterbitkan debitur masih memiliki kesempatan untuk melunasi utangnya, biaya dan bunga (Pasal 20 ayat 5 Undang-Undang Hak Tanggungan dan Penjelasannya). Dalam praktek yang terjadi selama ini meski pelelangan sudah diumumkan, namun jika debitur melakukan pembayaran atas utang beserta semua biaya dan bunga, maka pelelangan akan dihentikan. ${ }^{12}$

Bahwa setelah segala persyaratan dalam permohonan lelang telah dipenuhi, kemudian Kantor lelang melakukan penjualan dimuka umum (pelelangan) atas obyek Hak Tanggungan. Bahwa hasil dari penjualan tersebut digunakan untuk melunasi utang debitur, dan sisanya (apabila ada sisa) akan dikembalikan kepada debitur. Apabila hasil penjualan lelang tidak mencukupi untuk melunasi utang debitur, maka tidak berarti kewajiban debitur hapus begitu saja, akan tetapi utang debitur tersebut tetap menjadi kewajibannya untuk ditunaikan. Namun yang

\footnotetext{
${ }^{11}$ M Khoidin, Hukum Jaminan Hak-Hak Jaminan, Hak Tanggungan, dan Eksekusi Hak Tanggungan (Laksbang Yustitia 2017).[153].

${ }^{12}$ Retnowulan Sutantio dkk, Penelitian Tentang Perlindungan Hukum Eksekusi Jaminan Kredit (Departemen Kehakiman RI 1997).[18].
} 
berbeda, pemenuhan utang tersebut tidak dijamin lagi dengan suatu jaminan kebedaan khusus, tetapi dijamin dengan suatu jaminan umum sebagaimana dimaksud ketentuan Pasal 1131 dan Pasal 1132 BW.

Fiat eksekusi juga memiliki kendala, yakni kendala biaya yang relatif tinggi, dalam prosesnya juga terkadang memakan waktu cukup lama, sering diajukan gugatan/ bantahan dari debitur atau pihak ketiga. Selain itu terkadang pembeli kesulitan untuk melakukan pengosongan terhadap obyek Hak Tanggungan yang telah dibeli dari penjualan dimuka umum (pelelangan) tersebut, karena pihak Pengadilan Negeri melakukan penangguhan pengosongan. Jadi, kendala yang sering ditemui adalah sulit mencari pembeli lelang atau peminat pembeli lelang sedikit. ${ }^{13}$

b. Kepailitan

Kepailitan menurut ketentuan Pasal 1 angka 1 Undang-undang Nomor 37 Tahun 2004 tentang Kepailitan dan Penundaan Kewajiban Pembayaran Utang (selanjutnya disingkat Undang-undang Kepailitan) adalah "Sita umum atas semua kekayaan debitor pailit yang pengurusannya dan pemberesannya dilakukan oleh kurator di bawah pengawasan hakim pengawas sebagaimana diatur dalam UU ini”. Selanjutnya menurut M. Hadi Subhan "Kepailitan merupakan putusan pengadilan yang menyebabkan sita umum atas seluruh kekayaan debitor pailit, baik yang telah ada maupun yang akan ada dikemudian hari”. ${ }^{14}$ Pemaknaan kepailitan dalam Undang-undang Kepailitan tidak menunjukkan esensi dari kepailitan, namun hanya menunjukkan akibat hukum kepailitan, yaitu adanya sita umum atas kekayaan debitor pailit. ${ }^{15}$

Kepailitan memiliki prinsip dan ciri yang menunjukkan kedudukan Kepailitan sebagai upaya penagihan yang tidak lazim (oneigenlijke incassoprocedures). Menurut Wessels sebagaimana dikutip kembali oleh M.

\footnotetext{
${ }^{13}$ Ibid. [30].

${ }^{14}$ M. Hadi Shubhan, Hukum Kepailitan Prinsip, Norma dan Praktik di Peradilan (Kencana

${ }^{15}$ Ibid.[67].
} 2009).[1]. 
Hadi Subhan, dikatakan tidak lazim karena kepailitan disediakan sebagai sarana tekanan (pressie middel) untuk memaksa pemenuhan kewajiban oleh debitor. ${ }^{16}$

Bahwa kepailitan adalah upaya penagihan tidak lazim yang memberikan pengaturan yang sangat ketat terhadap pengurusan harta pailit. Bahkan bagi kreditur separatis, masih terdapat masa penagguhan hak (stay) selama sembilan puluh hari, apabila tidak dapat menjual objek jaminan tersebut, maka curator akan mengambil alih hak untuk mengeksekusi jaminan tersebut. ${ }^{17}$

Bahwa permohonan kepailitan tersebut, didasarkan pada ketentuan Pasal 2 ayat (1) Undang-undang Kepailitan, yang dapat disimpulkan bahwa terdapat tiga syarat yang harus dipenuhi, yaitu :

a. Debitur mempunyai minimal dua kreditur atau lebih;

b. Debitur belum atau tidak membayar lunas paling sedikit satu utang dan;

c. Utang tersebut telah jatuh waktu dan dapat ditagih;

Bahwa apabila kepailitan sebagaimana termaksud di atas, maka kepailitan dapat dijadikan sebagai salah satu cara tentang mekanisme apa yang digunakan untuk menyelesaikan masalah penolakan pelaksanaan eksekusi lelang oleh KPKNL terhadap objek Hak Tanggungan karena tidak dimohonkan oleh pemegang Hak Tanggungan peringkat pertama.

Bahwa melalui mekanisme kepailitan ini, maka kedudukan Kreditur dan Debitur tidak lagi terikat secara langsung, melainkan muncur perantara baru yakni Kurator yang berkedudukan sebagai "pengampu" harta pailit si Debitur. Termasuk yang nantinya akan melakukan penjualan di muka umum atau lelang adalah Kurator tersebut, yang kemudian hasil penjualannya akan digunakan untuk membayar utang Kreditur.

Bahwa kedudukan Bank sebagai kreditur membutuhkan bantuan dari kreditur lain untuk kemudian dapat mengajukan permohonan kepailitan ke Pengadilan Niaga, hal tersebut sebagaimana ketentuan Pasal 2 ayat (1) Undang-

\footnotetext{
${ }^{16}$ Ibid.[38].

${ }^{17}$ Gigih Imanreja 'Lelang Melalui Media Elektronik Terhadap Harta Pailit' (2014) Skripsi Universitas Airlangga.[32].
} 
undang Kepailitan. Bahwa untuk mendapatkan kreditur lain sebagaimana termaksud di atas, pihak Bank sebagai Kreditur dapat mencari informasi dari data Debitur sebagai nasabah pada Bank, agar dapat mengetahui informasi mengenai kreditur lain yang dapat ditarik dan diajak untuk mengajukan permohonan kepailitan terhadap debitur.

c. Gugatan Tata Usaha Negara ke Pengadilan Tata Usaha Negara dan/atau Gugatan Perbuatan Melawan Hukum ke Pengadilan Negeri.

Bahwa langkah ini dilakukan apabila penolakan KPKNL terkait dengan pelaksanaan penjualan objek hak tanggungan melalui pelelangan umum karena kedudukan Bank selaku pemegang Hak Tanggungan peringkat kedua tersebut termasuk Keputusan Tata Usaha Negara sebagaimana ketentuan Pasal 1 angka 9 Undang-undang Nomor 5 Tahun 1986 tentang Peradilan Tata Usaha Negara.

Sedangkan gugatan Perbuatan Melanggar Hukum diajukan karena perbuatan KPKNL yang menolak pelaksanaan penjualan objek hak tanggungan melalui penjualan dimuka umum (pelelangan) dengan alasan peringkat hak tanggungan, dikualifikasikan sebagai suatu Perbuatan Melanggar Hukum.

Bahwa upaya pengajuan gugatan Perbuatan Melawan Hukum dan juga gugatan Tata Usaha Negara sebagaimana termaksud di atas adalah upaya untuk menyelesaikan permasalahan hukum sehubungan dengan maraknya penolakan KPKNL terkait dengan pelaksanaan penjualan objek hak tanggungan melalui penjualan dimuka umum (pelelangan) yang diajukan oleh Bank selaku kreditur pemegang Hak Tanggungan peringkat kedua. Bahwa upaya pengajuan gugatan Perbuatan Melawan Hukum dan juga gugatan Tata Usaha Negara tersebut juga dapat bermanfaat bagi Bank-bank lain yang berkedudukan sebagai pemegang Hak Tanggungan peringkat kedua, agar permohonan pelaksanaan penjualan objek hak tanggungan melalui penjualan dimuka umum (pelelangan) dapat diabulkan oleh KPKNL.

\section{Kesimpulan}

Berdasarkan penjelasan yang telah diuraikan pada sub bab-sub bab 
sebelumnya, maka dapat disimpulkan sebagai berikut :

1. Pemegang Jaminan Hak Tanggungan sebagai Kreditur Preference memiliki hak untuk diutamakan dalam hal pembayaran utang Debitur. Bahwa dalam hal terdapat lebih dari satu pemegang Hak Tanggungan, maka berdasarkan ketentuan Pasal 6 Undang-undang Hak Tanggungan dan asas prioritas sebagaimana dimaksud dalam ketentuan Pasal 5 Undang-undang Hak Tanggungan, maka pemegang Hak Tanggungan peringkat pertama memiliki prioritas untuk menjual terlebih dahulu objek Hak Tanggungan atas kekuasaan sendiri melalui penjualan dimuka umum (pelelangan) serta mengambil pelunasan piutangnya terlebihdahulu dari hasil penjualan tersebut, dibanding dengan pemegang Hak Tanggungan Peringkat Kedua. Bahwa apabila kedudukan pemegang Hak Tanggungan peringkat pertama telah hapus karena adanya roya, maka kedudukan pemegang Hak Tanggungan Peringkat Kedua menjadi satu-satunya pihak yang memiliki prioritas untuk menjual objek Hak Tanggungan atas kekuasaan sendiri melalui penjualan dimuka umum (pelelangan) serta mengambil pelunasan piutangnya terlebih dahulu dari hasil penjualan tersebut;

2. Dengan menjadi kreditur peringkat kedua ternyata tidak menjamin kreditur dapat melakukan eksekusi terhadap objek Hak Tanggungan, hal ini dikarenakan KPKNL menjadikan Pasal 6 UUHT sebagai dasar pelaksanaan lelang bahwa jika kreditur peringkat kedua mengajukan eksekusi atas obyek Hak Tanggungan maka kreditur peringkat kedua harus terlebih dahulu menaikkan peringkatnya menjadi kreditur peringkat pertama ke Kantor Pertanahan, sedangkan Kantor Pertanahan menolak dengan alasan tidak ada prosedur yang mengatur hal tersebut. Sehubungan dengan hal tersebut, kreditur peringkat kedua dapat melakukan upaya hukum berupa mengajukan permohonan pelaksanaan eksekusi obyek Hak Tanggungan kepada Ketua Pengadilan, mengajukan permohonan pailit terhadap debitur dengan menggandeng 1 (satu) kreditur lain, mengajukan gugatan Tata Usaha Negara ke Pengadilan Tata Usaha Negara dan/atau mengajukan gugatan Perbuatan Melanggar Hukum ke Pengadilan Negeri. 


\section{Daftar Bacaan}

\section{Buku}

Boedi Harsono, Hukum Agraria Indonesia, Sejarah Pembentukan Undang-undang Pokok Agraria, Isi dan Pelaksanaannya (Djambatan 2007).

Kashadi, Hukum Jaminan Ringkasan Kuliah (Universitas Diponegoro 2009).

M. Khoidin, Hukum Jaminan Hak-Hak Jaminan, Hak Tanggungan, dan Eksekusi Hak Tanggungan (Laksbang Yustitia 2017).

M. Hadi Shubhan, Hukum Kepailitan Prinsip, Norma dan Praktik di Peradilan (Kencana 2009).

Munir Fuady, Hukum Bisnis dalam Teori dan Praktek (Buku Kedua, Citra Aditya Bakti 1994).

Philipus M. Hadjon, Perlindungan Hukum Bagi Rakyat di Indonesia (Peradaban 2007).

R. Subekti, Jaminan-jaminan Untuk Pemberian Kredit Menurut Hukum Indonesia (Cetakan I, Citra Adita Bakti 1989).

Rachmadi Usman, Pasal-pasal Tentang Hak Tanggungan atas Tanah (Djambatan 1999).

Retnowulan Sutantio dkk, Penelitian Tentang Perlindungan Hukum Eksekusi Jaminan Kredit (BPHN Departemen Kehakiman RI 1997).

Sutan Remy Sjahdeini, Hak Tanggungan : Asas-asas Ketentuan-ketentuan Pokok dan Masalah yang Dihadapi Oleh Perbankan (Suatu Kajian Mengenai Undang-undang Hak Tanggungan) (Alumni 1999).

Trisadini P. Usanti, Abd. Shomad, Hukum Perbankan (Kencana 2017).

\section{Skripsi}

Gigih Imanreja, 'Lelang Melalui Media Elektronik Terhadap Harta Pailit' (2014) Skripsi Universitas Airlangga.

\section{Perundang-undangan}

Undang-Undang Dasar Negara Republik Indonesia Tahun 1945 dan Amandemennya.

Kitab Undang-Undang Hukum Perdata (Burgerlijk Wetboek, Staatsblad 1847 No. 
23).

Undang-Undang Nomor 5 tahun 1960 tentang Peraturan Dasar Pokok-Pokok Agraria, Lembaran Negara Republik Indonesia Tahun 1960 Nomor 104.

Undang-Undang Nomor 4 Tahun 1996 tentang Hak Tanggungan Atas Tanah Beserta Benda-benda Yang Berkaitan Dengan Tanah, Lembaran Negara Republik Indonesia Tahun 1996 Nomor 42.

Undang-undang Nomor 37 Tahun 2004 tentang Kepailitan dan Penundaan Kewajiban Pembayaran Utang, Lembaran Negara Republik Indonesia Tahun 2004 Nomor 131.

Undang-undang Nomor 5 Tahun 1986 tentang Peradilan Tata Usaha Negara, Lembaran Negara Republik Indonesia Tahun 1986 Nomor 77.

HOW TO CITE: Dimas Nur Arif Putra Suwandi, 'Perlindungan Hukum Bagi Bank Pemegang Hak Tanggungan Peringkat Kedua Dalam Eksekusi Objek Hak Tanggungan' (2018) Vol. 1 No. 3 Media Iuris. 